\title{
What is History and Other Essays
}

Michael Oakeshott, edited by Luke O'Sullivan

Imprint Academic, Exeter, 2004, 454pp.

ISBN: 0907845835.

Contemporary Political Theory (2006) 5, 497-500. doi:10.1057/palgrave.cpt.9300251

A new collection of essays by such a distinguished political philosopher as Michael Oakeshott is always to be welcomed. Its value is not that it adds anything of significance to what we already know in a better and more sophisticated form, but that it satisfies the voyeur in us all. In this collection, we glimpse the intimate connection between a man and his thoughts, in various states of undress, before appearing fully clothed in such classics as Experience and Its Modes, On Human Conduct, and On History and other essays. Some poses are close to embarrassing, such as the 1943 'Peace with Germany', while others are close to exquisite, evocative and beautifully poised, such as 'The Voice of Education in the Conversation of Mankind' and the delightful analysis of Denys Hay's 'Europe, The Emergence of an Idea', in which the importance of discerning the different questions to which the book is an answer is attested with masterly precision.

The editor, Luke O'Sullivan, has an enviable knowledge of Oakeshott's published and unpublished works, and has himself written a very erudite and scholarly book on the philosophy of history of the last of the great 20th century idealists (O'Sullivan, 2003). The essays in Oakeshott's new volume are not arranged thematically. The editor has decided that there is merit is presenting them to us chronologically in order to experience the gradual revelation of thought. The introduction provides the reader with the thematic element, and with the intellectual affinities between unpublished and published works. The editor makes the substantive point that Oakeshott fundamentally changed his conception of philosophy over the course of his life. O'Sullivan contends over the course of Oakeshott's career we witness the gradual rejection of his 'early belief in the possibility of unconditional knowledge of reality. Instead, he came to favour the idea that understanding consisted ultimately of an irreducible plurality of modes or 'voices', to use the conversational metaphor of which he became so fond' (p. 5). I think this considerably overstates the case, and sets up a false dichotomy. Oakeshott says in Experience and its Modes that philosophy is experience without presupposition, reservation or arrest. What this meant in practice was that philosophy examined and questioned the postulates of those forms of experience that claimed knowledge, and convicted them of contradiction. The issue is effectively this: did Oakeshott's conception of 'understanding' radically change? I think not. Understanding requires relating what 
seeks to be understood, and is always in some sense already understood, to a context. A philosophical understanding of a historical statement must be considered in relation to history as an activity, and to history's place in the whole world of experience. Coherence is always the criterion by which the adequacy of statements is measured. When Oakeshott republished his introduction to Hobbes' Leviathan - in the same year as he published On Human Conduct - despite making many changes, he firmly adhered to the conception of understanding I have outlined. Consider his view of political philosophy: 'Even if we accept the standards and valuations of our civilization, it will be only by putting an arbitrary closure on reflection that we can prevent the consideration of the meaning of the general terms in which those standards are expressed: good and evil, right and wrong, and justice and injustice. And, turning, we shall catch sight of all that we have learned reflected in the speculum universitatis' (Oakeshott, 1975a, b, 5). In the three essays on history he published in 1983, Oakeshott is concerned to explore the distinct modal conditions that constitute history. The study is concerned only to determine the postulates of history, not the truth of historical conclusions, only the conditions in terms of which they may be recognized as conclusions. It is true that Oakeshott does not go on to relate history to experience as a whole, but silence does not signify abandonment. If it did, we would have to conclude that because he made no mention of it in a 1936 lecture on history that he had abandoned the idea of a concrete totality of experience (Oakeshott, 1936, 71-81). After 2 years, he reiterated what he took philosophy to be: the attempt to relate a subject to the concrete totality of experience. Why? Because this constitutes the complete context incapable of being turned by criticism into a text itself requiring a context (Oakeshott, 1938, 351).

There must be a reason why O'Sullivan and others claim that a fundamental shift has taken place. The weight of their argument rests on the metaphor (and it is nothing more than a metaphor for the relations among idioms of discourse for Oakeshott) of voices in a conversation. In What is History? Conversation is the analogy used for life in preference to a game of cards. Plato civilized philosophy by relating it to conversation, making the relation dialectic rather than eristic (p. 197 and pp. 193-194). In his most famous discussion of the conversational relationship, Oakeshott uses the metaphor to elucidate the relation in which each language or idiom of thought stands to each other (Oakeshott, 1962, 137-196). O'Sullivan uses this latter essay as grounds for his contention that philosophy is now a voice among other voices, with no priority or special authority. The idea of a conversation is not a significant change of emphasis from his early philosophy. It is a new metaphor better able to characterize the relation he had in mind between the different modes. It is not that philosophy is a voice in this conversation that is important, but that it is a voice of a different kind. It springs from the conversation, and is parasitic on 
the other voices. It explores the quality and style of each voice and its relation to the others. Philosophy is unusually adept at conversation because 'there is no body of philosophical 'knowledge' to become detached from the activity of philosophizing' (Oakeshott, 1962, 201).

Three contentions about philosophy emerge: (i) it is not eristic, and does not attempt to persuade; (ii) it is parasitic on the other voices; and (iii) it is not a body of knowledge.

On the first point, there is a lifelong consistency. Philosophy consists not in 'persuading others, but in making our own minds clear'. It is noncompetitive and 'something independent of the futile attempt to convince or persuade' (Oakeshott, 1933, 7). It sounds, then, very like what he takes conversation to be.

Nor does he deviate on the second contention. Experience, or what is going on, is one undifferentiated whole. Understanding involves making identifications in terms of postulates. Philosophical activity questions the postulates, and hence is parasitical on the modes they constitute. On the third contention, not even in Experience and its Modes is there a suggestion that philosophy is a body of knowledge. Oakeshott says at the start that he was not presenting us with a system or with universal truths. It was a provisional point of view that he offered. Philosophy had no exclusive source of knowledge, 'it was merely experience become critical of itself' (Oakeshott, 1933, 82). What distinguishes philosophy from the modes is not absolute certainty $v s$ lesser degrees of truth, but the determination to investigate every presupposition it encounters, in other words, to be permanently en route. It is a method, or way of thinking, aimed at achieving intelligibility, not an accumulated body of knowledge. Oakeshott confirms this, and by implication denies O'Sullivan's contention that Oakeshott believed in the attainment 'of unconditional knowledge of reality' (p. 5): 'Philosophy is, then, not a particular kind of experience; and certainly it has no peculiar and exclusive source of knowledge. It is merely experience become critical of itself, experience sought and followed entirely for its own sake' (Oakeshott, 1933, 82).

For the Oakeshott aficionado, this collection is a valuable addition to the oeuvre that constitutes the context of Oakeshott's mature deliberations.

\section{References}

Oakeshott, M. (1933) Experience and its Modes, Cambridge: Cambridge University Press.

Oakeshott, M. (1936) 'History and the Social Sciences', in The Institute of Sociology (ed.), The Social Sciences, London: Le Play House Press, pp 71-81.

Oakeshott, M. (1938) 'The concept of a philosophical jurisprudence', Politica 3: 203-222, 345-360.

Oakeshott, M. (1962) 'The Voice of Poetry in the Conversation of Mankind', in Rationalism in Politics and other Essays, London: Methuen, pp. 197-247.

Oakeshott, M. (1975a) Hobbes on Civil Association, Oxford: Blackwell. 
Oakeshott, M. (1975b) On Human Conduct, Oxford: Oxford University Press.

Oakeshott, M. (1983) On History and other Essays, Oxford: Blackwell.

O’Sullivan, L. (2003) Oakeshott on History, Exeter: Imprint Academic.

David Boucher

Cardiff School of European Studies, Cardiff University, UK.

\author{
Margins of Disorder: New Liberalism and the Crisis of European Consciousness \\ Gal Gerson \\ State University of New York Press, Albany, NY, 2004, vii +239pp. \\ ISBN: 0791461475.
}

Contemporary Political Theory (2006) 5, 500-502. doi:10.1057/palgrave.cpt.9300265

The transformation of liberal political theory in the late 19th and early 20th century remains a fertile subject for research in the history of political thought. A number of important studies have demonstrated that in this period so-called 'classical' liberalism underwent a significant crisis and rebirth, triggered by the rise of democratic politics, the sharpening of class conflict, and shifts in scientific understanding. The characteristic features of liberal ideology were reconsidered, perhaps above all the emphasis on individual freedom as consisting in the silence of the law, and instead liberal theories began to stress the importance of the community for the flourishing of the individual and the need for positive action by the state to secure effective individual liberty. This 'new liberalism', associated in Britain with the theorists and publicists Leonard Hobhouse and John Hobson (and more indirectly with philosophers like TH Green), helped to make the intellectual climate more hospitable to the claims of the working class and even influenced the eventual emergence of the welfare state.

In Margins of Disorder, Gal Gerson takes up this now familiar story and expands our understanding of it with an arresting study of the relationship between the new liberalism and the rise of counter-enlightenment ideas. Tempting as it is to view the critique of modernity as simply the latest intellectual fashion fresh from the boutiques of Paris, in fact postmodernism has a long and complex history. As Gerson demonstrates, many of the key ideas first emerged in the 'revolt against reason' of the late 19th century, forming a significant and neglected influence on the development of the new liberalism. By the 'revolt against reason', Gerson means 'the late 19th-century intellectual reaction that composed Friedrich Nietzsche, Sigmund Freud, Emile 